\title{
Diversity of endophytic bacteria and microfungi in Syzygium cumini fruit from West Java, Indonesia
}

\author{
IDA INDRAWATI ${ }^{\natural}$, NIA ROSSIANA $"$, MUHAMMAD FAIZAL FATHURROHIM $\bullet \bullet$ \\ Department of Biology, Faculty of Mathematics and Natural Science, Universitas Padjadjaran, Jl. Raya Bandung-Sumedang Km. 21, Sumedang 45363, \\ West Java, Indonesia. Tel./fax.: +62-22-7796412, `email: ida.indrawati81@gmail.com, •v niarossiana@yahoo.com, •v• faizalmaret26@gmail.com
}

Manuscript received: 21 April 2021. Revision accepted: 27 August 2021.

\begin{abstract}
Rossiana N, Fathurrohim MF, Indrawati I. 2021. Diversity of endophytic bacteria and microfungi in Syzygium cumini fruit from West Java, Indonesia. Biodiversitas 22: 3943-3948. Syzygium cumini L. Skells is a native evergreen tropical tree in Southeast Asia belong to the Myrtaceae family, known as the Java plum, jambul, jambolan, jamblang, or jamun. The bacterial and fungal endophytes associated with fruit have not been determined and functionally characterized. The endophytic microbes live inside the surface-sterilized fruits and have no visibly harmful effects on the plants. The purposes of the study were to isolate, characterize, and determine the diversity of endophytic bacteria and fungi in $S$. cumini fruit. The endophytes from $S$. cumini fruit were observed morphologically for identification. The result of isolation and identification showed there are four bacterial isolate endophytes (B. cereus, B. subtilis, B. megaterium, and Bacillus sp.) and four fungal endophytes (Candida guilliermondii, Penicillium sp., Mycelia sterilia, and Aspergillus sp.) isolated from S. cumini fruit.
\end{abstract}

Keywords: Bacterial endophyte, biodiversity, fungal endophyte, jamblang, Sygizium cumini

\section{INTRODUCTION}

With its thousands of islands, Indonesia has a myriad wealth of biological resources, especially tropical fruits. Approximately 329 types of fruits, both indigenous and introduced, could be found in Indonesia. Two hundred and sixty-six species of Indonesian indigenous fruits mostly grow wild in the forest and only a small portion has been cultivated (Hermanto et al. 2013).

Syzygium cumini L. Skeels (Java plum, jambul, jambolan, jamblang, or jamun) is one of the plants that have many benefits in Indonesia. However, Indonesian people do not know much about the benefits and nutritional value of $S$. cumini fruit. S. cumini fruit contains flavonoids, quinones, steroids, and polyphenols (Marliani et al. 2014). So, it might be potential as a medicinal plant.

The plant is the host for various types of endophytic microbes. Natural products produced by endophytic microbes were reported to exhibit a wide range of biological activities and are categorized into various categories of chemical compounds including alkaloids, terpenoids, steroids, lactones, phenolic compounds, quinones, and lignans (Anjum and Chandra 2015).

The internal non-sterile plant tissue is inhabited by various types of fungi and bacteria known as endophytes (Goryluk et al. 2009). Endophytic microbes in plant tissues do not cause disease symptoms in their hosts (Anjum and Chandra 2015). Endophytic microbes can obtain nutrients to complete their life cycle from the host plant, while the host gets protection against plant pathogens from compounds produced by endophytic microbes (Ariyanto et al. 2013).
Endophytic microbes can have a mutualistic symbiosis with their host plant. The search for endophytic microbes from different plant species in different ecosystems will be beneficial. The diversity of endophytic microbes is underexplored although they are a great resource for application in the fields of agriculture, medicine, pharmacy, farm, and industry (Zhang et al. 2016). The diversity of microorganisms i.e., the diversity of endophytic microbes in $S$. cumini fruit is very important, to be studied.

Endophytic bacteria generally enter the plant tissues through roots and plant parts exposed to direct air such as flowers, stems, and cotyledons (Desriani et al. 2014). Endophytic bacteria can be isolated through internal plant tissue in which its outer surface has been sterilized (Munif et al. 2012).

Endophytic fungi are a group of fungi that colonize living and internal tissues of plants without causing any immediate, overt negative effects (Padhi et al. 2013). Endophytic fungi have an important role in their dead hosts to initiate biological degradation to start the nutrient recycling process (Shekhawat et al. 2010).

Studies on the diversity of endophytic bacteria and fungi in $S$. cumini fruit in Indonesia have not been conducted. This study was conducted to determine the diversity of bacteria and endophytic fungi in $S$. cumini fruit.

\section{MATERIALS AND METHODS}

\section{Plant material}

Syzygium cumini fruit was collected from the plant grow in Padjadjaran University Campus, Sumedang, West Java, Indonesia. 


\section{Isolation of endophytic bacteria}

Syzygium cumini fruits were washed under running water for 5 minutes and then dipped in $96 \%$ ethanol for 2 seconds, followed by rinsing with sterile distilled water for 30 seconds and then rinsed using $1 \% \mathrm{NaOCl}$ solution for 5 minutes. As much as 100 grams of the fruits, added with 9 $\mathrm{ml}$ of sterile physiological $\mathrm{NaCl}$, and then finely crushed. As much as $1 \mathrm{ml}$ of finely crushed fruits was diluted to $10^{7}$ dilutions. One ml of diluted crushed fruit was inoculated on nutrient jell for the last three dilutions $\left(10^{-5}, 10^{-6}\right.$, and 10-7) and incubated for 24 hours at $37^{\circ} \mathrm{C}$. After incubation, one ose of each species of different morphological bacterial colonies were subcultured onto a nutrient agar slope. Pure bacterial isolate was identified.

\section{Identification of endophytic bacteria}

Pure bacterial cultures were identified microscopically, i.e., colony color, elevation, surface, and bacterial colonies. Gram-staining carried out microscopic observation to determine bacterial cell shape and biochemical characterization was performed using VITEK 2.0 compact system.

\section{Isolation of endophyte fungi}

The fruit was washed under running water for 5 minutes, then rinsed with $70 \%$ alcohol for 5 minutes, followed by soaking in $1 \% \mathrm{NaOCl}$ solution for 5 minutes and then drained. The fruit was then rinsed with sterile distilled water for one minute twice. Then the fruit was crushed and was diluted with series from $10^{-1}$ to $10^{-7}$ in medium Potato Dextrose Agar. The last three dilutions (1ml) were added into the petri dish, as much as $1 \mathrm{ml}$ and 3 last dilutions were inserted into a petri dish containing the PDA medium and were then homogenized, followed by incubation at room temperature for 48-72 hours. Emerging fungi on Petri dishes were subcultured on PDA to obtain a pure culture.

\section{Identification of endophyte fungi}

The moist chamber performed fungal identification. Macroscopic observations were carried out including colony color, colony surface, concentric circle, and radial surface lines of the colony. Microscopic observations included the morphology of spore, sporangium, and conidia.

\section{RESULTS AND DISCUSSION}

Isolation of endophytic bacteria and fungi from $S$. cumini fruit resulted in 4 isolates of bacteria (FIN 2, FIN 3, FIN 4, and FIN 11) and 4 isolates of fungi. Based on Gramstaining, the four endophytic bacteria were Gram-positive bacilli. Macroscopic characters of endophytic bacteria FIN 2 were a white colony, round shape, flat colony elevation, flat edge, and smooth surface (Figure 1.A). Microscopically, endophytic bacteria FIN 2 is a purple Gram-positive bacteria bacilli (Figure 1.B). Endophytic bacteria FIN 3 has macroscopic characteristics of spherical shaped colonies, jagged edges, flat elevation, rough surface, and slightly greenish-white (Figure 2A), and microscopic characteristics as Gram-positive bacilli (Figure 2.B). Endophytic bacterial FIN 4 has macroscopic characteristics of spherical shaped colonies, flat edges, flat elevations, smooth, and white surface (Figure 3.A) with microscopic characteristics as Gram-positive bacilli (Figure 3.B). Endophytic bacteria FIN 11 has macroscopic characteristics of spherical-shaped colonies, jagged edges, raised elevations, rough surface with white and greenish margins in the middle (Figure 4.A), and microscopic characteristics as Gram-positive (Figure 4.B).

The results of the biochemical character of four endophytic bacteria from $S$. cumini fruit using VITEK Compact 2.0 were prested Table 1 .

The results of the identification of endophytic fungi from S. cumini fruit (MFFJB, MFFJE, MFFJF, and MFFJG) were presented in Table 2.

\section{Discussion \\ Bacillus cereus (FIN 3)}

Bacillus cereus is a Gram-positive, aerobic, facultatively anaerobic, spore-forming, and mesophilic bacterium, with growth temperatures from $10^{\circ} \mathrm{C}$ to $48^{\circ} \mathrm{C}$ with optimal growth between $28^{\circ} \mathrm{C}$ and $35^{\circ} \mathrm{C}$. B. cereus measures 1 × $3-4 \mu \mathrm{m}$. Most $B$. cereus strains are motile via peritrichous flagella, grow on solid growth media as irregular colonies, use glucose as a source of carbon (but not mannitol, arabinose, or xylose), hydrolyze starch and gelatin, show hemolytic activity, are resistant to ampicillin, and display pronounced lecithinase activity (Vilas-Boas et al. 2007). The endophytic B. cereus isolated from Garcinia xanthochymus based nanoparticles has the potential to be developed as promising antibacterial and antioxidant agents (Mujaddidi et al. 2021).

\section{Bacillus megaterium (FIN 2)}

Bacillus megaterium is a Gram-positive spore-forming bacteria. As most of the spore-formers, it is usually found in the soil, from which it can easily be transmitted to the foods we consume (Periago et al. 2006). From macroscopic and microscopic observations and biochemical tests, it is shown that B. megaterium is concave, smooth, and milkwhite. The cell morphology shows that the cell is rodshaped, Gram-positive, and sporous (Andriani et al. 2017). Some B. megaterium proteins are very important in the food industry and pharmacy. B. megaterium secretes a variety of enzymes, ranging from amylases used in the bakery industry to penicillin amidase used to manufacture new synthetic antibiotics (Mobitec 2008). B. megaterium can also produce several other enzymes, such as mutarotase, glucose dehydrogenase, $\beta$-galactosidase, and cellulose (Andriani et al. 2017).

\section{Bacillus subtilis (FIN 4)}

Bacillus subtilis is a Gram-positive, aerobic, nonencapsulated, mobile, and spore-bearing bacterium, a basil chain with a size of $0.8-0.7$ or 2-3 um, commonly found in nature. Bacterial colonies have a white or slightly yellowish, rough, and opaque surface. Grow in the mesophilic temperature range of $25-35^{\circ} \mathrm{C}$. Its active form is 
usually spore-shaped. Therefore, it can survive in difficult conditions (Saleh et al. 2014). B. subtilis is useful for biotechnology as well as industrial and agricultural applications. B. subtilis can directly fight pathogens by producing a secondary metabolite of extracellular lytic enzymes to inhibit growth by quorum quenching to disrupt the communication of cell-to-cell expression from infectious expression in pathogenic bacteria (Alina et al. 2015).

\section{Bacillus sp. (FIN 11)}

The genus Bacillus is Gram-positive bacteria, a stem cell shape with a cell size of 0.3-2.2 to 1.2-7.0 $\mu \mathrm{m}$ (Alina et al. 2015). It can also move freely and has good competence and survivability on rhizosphere and facultative anaerobes so that it can adapt to living in the soil under various environmental conditions (Yanti et al. 2018). Bacillus sp. can produce digestive enzymes such as proteases and amylases that can help digestion and produce short-chain organic acids with antimicrobial properties (Sumardi et al. 2012). Bacillus can also be used as potential biofertilizers, biopesticides, and non-pathogenic to plants.

\section{Candida guiliermondii (MFFJB)}

Candida guilliermondii is the most common opportunistic fungus, a normal flora present in human skin and mucosal surfaces, but occasionally the cause of chronic onychomycosis, acutely osteomyelitis, septic arthritis, endocarditis, fungemia, and invasive infections (Girmenia et al. 2006). The yeast cells of $C$. guilliermondii are both rounded and ellipsoidal, the length is $4.21 \pm 0.3 \mu \mathrm{m}$ and the diameter is $2.29 \pm 0.1 \mu \mathrm{m}$ (Hovnanyan et al. 2019). Cells of C. guilliermondii are heterogeneous, mostly elongated in shape (approximately 2, 9, $10 \mathrm{~cm}$ ). In contrast to Candida albicans, C. guilliermondii is unable to produce true hyphae. Nevertheless, under certain conditions, such as nitrogen or carbon deficiency, these budding yeast can efficiently switch to pseudohyphal structure harboring blast conidia circlet (Koehler et al. 1999; Papon et al. 2013).

\section{Penicillium sp. (MFFJE)}

Penicillium is a genus of one the most fungi found in different environmental and suitable environmental (temperature, humidity, pH). According to Subowo (2015) Penicillium sp. can decompose cellulose and lignin compounds into simple carbon compounds required by microbes as an energy source (Carbon source). Penicillium species produce various secondary metabolites such as antibacterial (Petit et al. 2009). Many Penicillium produced the different chemical types of secondary metabolite, while some of them are important in the field of medicine. Others are used for the production of mycotoxins, important drugs, and some of the Penicillium species are used in industry, especially penicillin production (García-Estrada et al. 2011).
Table 1. Biochemical characters of endophytic bacteria isolated from Sygizium cumini fruit

\begin{tabular}{|c|c|}
\hline & Endophytic bacterial isolate \\
\hline bio & $\begin{array}{llll}\text { FIN } 2 & \text { FIN } 3 & \text { FIN } 4 & \text { FIN } 11\end{array}$ \\
\hline
\end{tabular}

Beta-xylosidase

L-lysine-arylamidase

L-aspartate- arylamidase

Leucine arylamidase

Phenylalanine arylamidase

L-proline arylamidase

Beta-galactosidase

L-pyrrolidonyl- arylamidase

Alpha-galactosidase

Alanine arylamidase

Tyrosine arylamidase

Beta-n-acetyl-glucosaminidase

Ala-phe-pro arylamidase

Cyclodextrin

D-galactose

Glycogen

Myo-inositol

Methyl-A-D-glucopyranoside acidification

Ellman

Methyl-D-xyloside

Alpha-mannosidase

Maltotriose

Glycine arylamidase

D-Mannitol

D-Mannose

D-Melezitose

N-Acetyl-D-glucosamine

Palatinose

L-Rhamnose

Beta-glucosidase

Beta-mannosidase

Phosphoryl choline

Pyruvate

Alpha-glucosidase

D-tagatose

D-trehalose

Inulin

D-glucose

D-ribose

Putrescine assimilation

Growth in $6,5 \% \mathrm{NaCl}$

Kanamycin resistance

Oleandomycin resistance

Esculin hydrolyze

Tetrazolium RED

Polymixin_B resistance

Probabilitas

FIN 2 FIN 3 FIN 4 FIN 11

$\begin{array}{llll}- & - & - & - \\ - & - & - & -\end{array}$

$+\quad-\quad-$

$+\quad-\quad+\quad+$

$+\quad+\quad+$

$\begin{array}{llll}+ & + & + & + \\ - & + & - & -\end{array}$

$+\quad-\quad+$

$\begin{array}{lll}- & +\end{array}$

$+\quad+\quad+$

$+\quad+\quad-$

$+\quad+$

$\begin{array}{llll}- & + & -\end{array}$

$+\quad+\quad+$

$\begin{array}{lll}+ & + & +\end{array}$

$+\quad-\quad-\quad-$

$+\quad-\quad-$

- - - -

$\begin{array}{lll}- & + \\ + & + & +\end{array}$

$\begin{array}{lll}-1 & -1 \\ - & - & -\end{array}$

$\begin{array}{lll}- & -1 \\ - & - & -\end{array}$

$+\quad+\quad+$

$\begin{array}{llll}+ & - & - & +\end{array}$

$+\quad-\quad+\quad+$

$\begin{array}{lll}+ & - & +\end{array}$

$\begin{array}{lll}- & -1 \\ - & -\end{array}$

$+\quad+\quad-$

$+\quad-\quad+\quad-$

$\begin{array}{lll}- & -1 \\ - & - & -\end{array}$

$+\quad+\quad+$

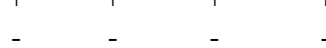

-
$-\quad-$

$\begin{array}{llll}- & - & + & +\end{array}$

$+\quad+\quad-\quad+$

- $\quad$ - $\quad-$

$+\quad+\quad+\quad+$

$\begin{array}{lll}+ & + & +\end{array}$

$+\quad+\quad-$

$+\quad+\quad-\quad+$

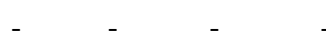

$+\quad+\quad+$

- + -

$\begin{array}{lll}- & + & -\end{array}$

$\begin{array}{llll}- & - & - & +\end{array}$

- $-1+$

$\begin{array}{llll}- & - & - & +\end{array}$

$93 \% \quad 94 \% \quad 87 \% \quad-$

Result of identification 
Table 2. Identification and characteristic of endophytic fungi from Sygizium cumini fruit using moist chamber

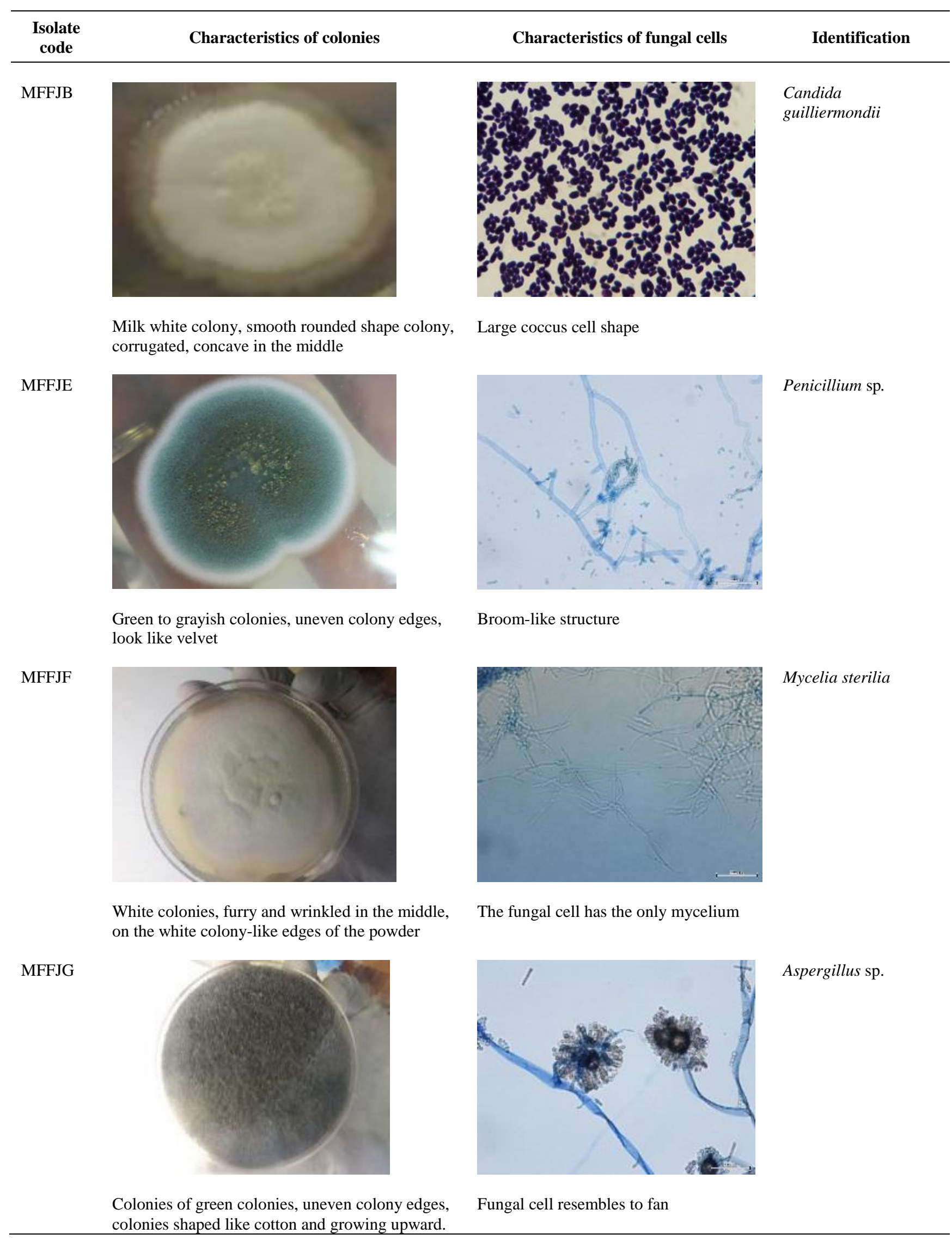




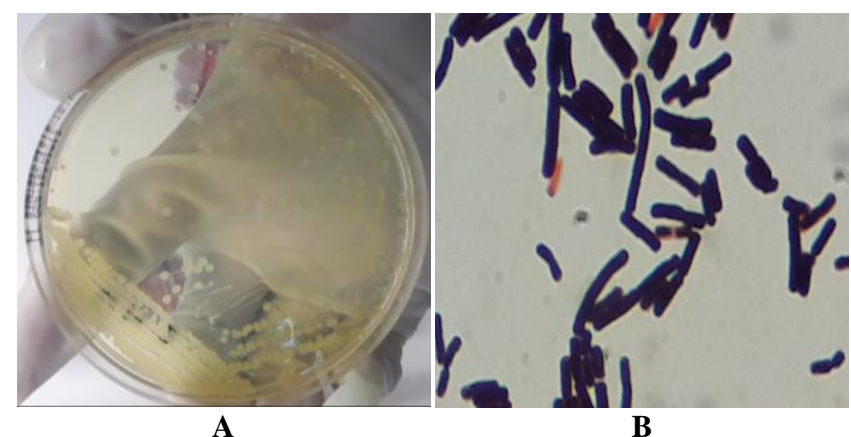

Figure 1. The bacterial isolate of FIN 2 (Bacillus cereus) on TSA (A) and Gram Stained FIN 2 (B)

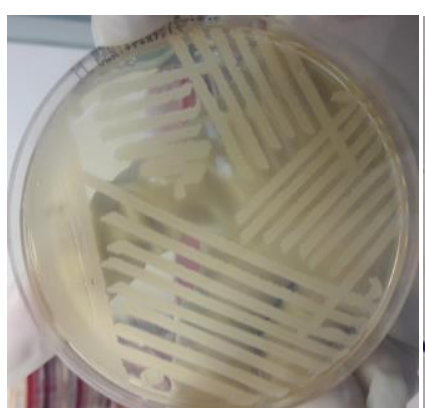

A

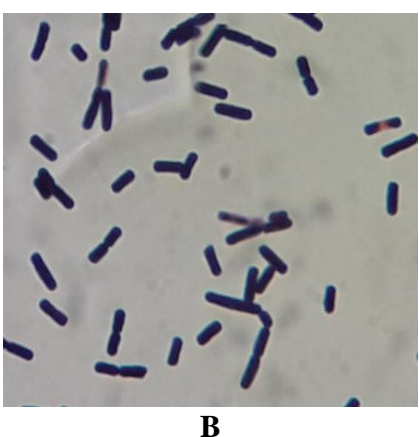

B
Figure 2. The bacterial isolate of FIN 3 (Bacillus megaterium) on TSA (A) and Gram Stained FIN 3 (B)

\section{Mycelia sterilia (MFFJF)}

Mycelia sterilia is a non-forming spore fungus. Endophytic fungus Mycelia sterilia is often found in the bifurcated mycelium assemblies, erect conidia, globose vesicles with uniseriate sterigmata with conidia chain basipetal succession (Srinivas et al. 2015). Based on research Carbungco et al. (2017), Mycelia sterilia has a floccose texture, white greenish peripheral with a circular filamentous zone. Mycelia sterilia has hyphae with a length of $40 \mu$ and a diameter of $8 \mu$ and has absent spores. Mycelia sterilia is also found in vegetables.

\section{Aspergillus sp. (MFFJG)}

Aspergillus is probably the most widespread group of fungi in the human environment. Many species are found in a variety of substrates, including soil, forage products, various types of food products, dust, organic debris, and decomposing matter. Aspergillus species play an essential role in the recycling of carbon and nitrogen sources. Many Aspergillus species, including important pathogenic species, do not have special nutritional requirements and can grow in simple media, such as glucose-asparaginephosphate broth, which contains a single protein hydrolysate (Gugnani 2003). Aspergillus has the characteristics of a spore-bearing structure called a conidial head, a basal foot of a bicep. The leg cells have more or less perpendicular hyphae and a vesicular conidiophore,

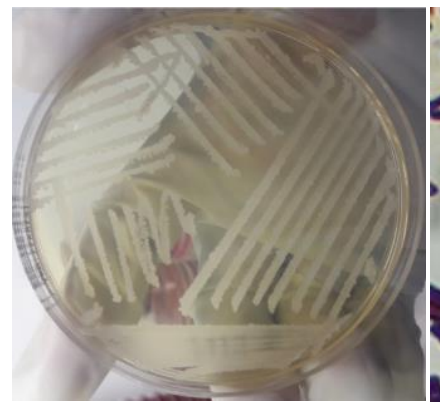

A

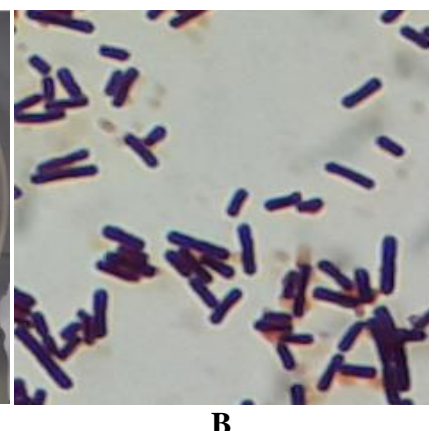

$\mathbf{B}$
Figure 3. The bacterial isolate of FIN 4 (Bacillus subtilis) on TSA (A) and Gram Stained FIN 4 (B)

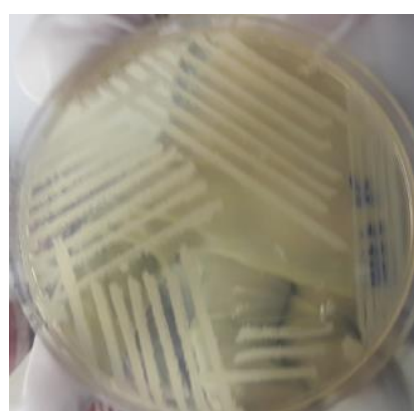

A

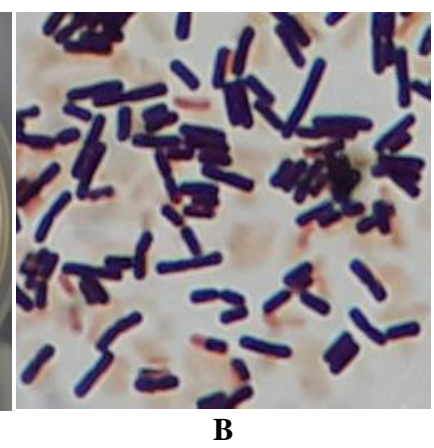

B
Figure 4. The bacterial isolate of FIN 11 (Bacillus sp.) on TSA (A) and Gram Stained FIN 11 (B)

having one or two synchronous cell layers and asexually formed spores known as conidia produced by phialides. The head of conidia of Aspergillus may be uniseriate or biseriate (Nyongesa et al. 2015).

In conclusion, the isolation of endophytic bacteria and fungus from $S$. cumini fruit successfully obtained 4 species of bacteria and 4 species of fungi. Endophytic bacteria from $S$. cumini fruit were identified as Bacillus cereus, $B$. megaterium, B. subtilisin, and Bacillus sp. Identified endophytic fungi from $S$. cumini fruit consisted of Candida guilliermondii, Penicillium sp, Mycelia sterilia, and Aspergillus sp.

\section{REFERENCES}

Alina SO, Constantinscu F, Petruta CC. 2015. Biodiversity of Bacillus subtilis group and beneficial traits of Bacillus species useful in plant protection. Romanian Biotechnol Lett 20 (5): 10737-10750.

Andriani Y, Rochima E, Safitri R, and Rahayu SR. 2017. Characterization of Bacillus megaterium and Bacillus mycoides bacteria as probiotic bacteria in fish and shrimp feed. ICSAFS Conf Proc 2017: 127-135. DOI: $10.18502 / \mathrm{kls} . v 2 \mathrm{i} 6.1029$

Anjum N, Chandra N. 2015. Endophytic bacteria: Optimization of isolation procedure from various medicinal plants and their preliminary characterization. Asian J Pharm Clin Res 8(4): 233-238.

Ariyanto EF, Abadi AL, Djauhari S. 2013. Keanekaragaman jamur endofit pada daun tanaman padi (Oryza sativa L) dengan sistem Pengelolaan Hama Terpadu (PHT) dan konvensional di Desa Bayem, Kecamatan 
Kasembon, Kabupaten Malang. Jurnal Hama dan Penyakit Tumbuhan 1(2): 37-51. [Indonesian]

Carbungco ES, Pedroche NB, Panes VA, De la Cruz TE. 2015 Identification and characterization of endophytic fungi associated with the leaves of Moringa oleifera Lam. In: I Int Symp Moringa 1158: 373-380. DOI: 10.17660/ActaHortic.2017.1158.42

Desriani, Safira PUM, Bintang M, Rivai A, Lisdiyanti P. 2014. Isolasi dan karakterisasi bakteri endofit dari tanaman binahong dan katepeng China. Jurnal FK Unand 3(2): 89-93. DOI: 10.25077/jka.v3i2.33 [Indonesian]

García-Estrada C, Ullán RV, Albillos SM, Fernández-Bodega MÁ, Durek P, von Döhren H, Martín JF. 2011. A single cluster of coregulated genes encodes the biosynthesis of the mycotoxins Roquefortine $\mathrm{C}$ and Melegrin in Penecillium chrysogenum. J Chem Biol 18: 1499-1512. DOI: $10.1016 /$ j.chembiol.2011.08.012.

Gugnani, H C. 2003. Ecology and taxonomy of pathogenic Aspergilli. Front Biosci 8: 346-357. DOI: 10.2741/1002

Girmenia C, Pizzarelli G, Cristini F, Barchiesi F, Sperghini E, Scalise Martino P. 2006. Candida guilliermondii fungemia in patients with hematologic malignancies. J Clin Microbiol 44 (07): 2458-2464. DOI: 10.1128/JCM.00356-06

Goryluk A, Burlaga HB, Blaszczyk M. 2009. Isolation and characterization of bacterial endophytes of Chelidonium таји L. Polish J Microbiol 58 (4): 355-361.

Hovnanyan KO, Gasparyan HV, Marutyan SV, Navasardyan LH, Trchounian AH. 2019. Comparative structural analysis of yeast Candida guilliermondii NP-4 Cultivated with and without nitrogen source. Proc Yerevan State Univ Chem Biol 53 (1): 53-58.

Hermanto C, Indrianti NLP, Hardiati S. 2013. Keragaman dan Kekayaan Buah Tropika Nusantara. Badan Penelitian dan Pengembangan Pertanian. Kementrian Pertanian. IAARD Press, Jakarta. [Indonesian]

Koehler AP, Chu KC, Houang ET, Cheng AF. 1999. Simple, reliable, and cost-effective yeast identification scheme for the clinical laboratory. J Clin Microbiol 37 (2): 422-426. DOI: 10.1128/JCM.37.2.422426.1999

Marliani L, Kusriani H, Sari NI. 2014. Aktivitas antioksidan daun dan buah jamblang (Syzygium cumini L.) Skeel. Prosiding SNaPP2014 Sains, Teknologi, dan Kesehatan 4 (1): 201-206. [Indonesian]

Mobitec. 2008. Bacillus megaterium Protein Expression System. Molecular Biotechnology. Mobitec, Germany.

Mujaddidi N, Nisa S, Ayoubi SA, Bibi Y, Khan S, Sabir M, Zia M, Ahmad S, Qayyum A. 2021. Pharmacological properties of biogenically synthesized silver nanoparticles using endophyte Bacillus cereus extract of Berberis lyceum against oxidative stress and pathogenic multidrug-resistant bacteria. Saudia J Biol Sci 1-9. DOI: $10.1016 /$ j.sjbs.2021.07.009.

Munif A, Johannes H, Richard S. 2012. Isolation of endophytic bacteria from tomato and their biocontrol activities against fungal disease. J Microbiol Indones 6 (4): 148-156. DOI: 10.5454/mi.6.4.2.
Nyongesa BW, Okoth S, Ayugi V. 2015. Identification key for Aspergillus species isolated from maize and soil of Nandi County, Kenya. Adv Microbiol 5: 205-229. DOI: 10.4236/aim.2015.54020

Padhi L, Mohanta YK, Panda SK. 2013. Endophytic fungi with great promises: A Review. J Adv Pharm Educ Res 3 (3): 152-170.

Papon N, Savini V, Lanoue A, Simkin JA, Creche J, Giglioli-Guivarc'h N, Clastre M, Courdavault V, Sibirny AA. 2013. Candida guilliermondii: Biotechnological applications, perspectives for biological control, emerging clinical importance and recent advances in genetics. Curr Genet 59 (3): 73-90. DOI: 10.1007/s00294-0130391-0.

Periago PM, Conesa R, Delgado B, Fernandez PS, Palop A. 2006. Bacillus megaterium spore germination and growth inhibition by a treatment combining heat with natural antimicrobials. Food Technol Biotechnol 1 (44): 17-23.

Petit P, Lucas EMF, Abreu ML, Pfenning LH, Takahashi JA. 2009. Novel antimicrobial secondary metabolites from Penicillium sp. isolated from Brazilian cerrado soil. Electr J Biotechnol 12 (4): 8-9. DOI: 10.2225/vol12-issue4-fulltext-9

Saleh F, Kheirandish F, Azizi H, Azizi M. 2014. Molecular diagnosis and characterization of Bacillus subtilis isolated from Burn Wound in Iran. Res Mol Med 2 (2): 40-44. DOI: 10.18869/acadpub.rmm.2.2.40

Shekhawat KK, Rao DV, Batra A. 2010. Morphological study of endophytic fungi inhabiting leaves of Melia azedarach L. Intl J Pharm Sci Rev Res 5 (3): 117-180.

Subowo YB. 2015. Pengujian aktifitas jamur Penicillium sp. R7.5 dan Aspergillus niger NK pada media tumbuh untuk mendukung pertumbuhan tanaman padi di lahan salin. Pros Sem Nas Masy Biodiv Indon 1 (5): 1136-1141. DOI: $10.13057 / \mathrm{psnmbi} / \mathrm{m} 010529$. [Indonesian]

Srinivas RP, Nigam A, Aruna J, Silva WCD, Chikkaswanny BK. 2015. An investigation of biodiversity of endophytic fungi associated with some medical plants. Intl J Adv Res Eng Appl Sci 4 (2): 27-44.

Sumardi S, Ekowat CN, Handayani K, Nurhayati N. 2012. Isolasi dan karakteristik Bacillus sp. penghasil antimikroba dari saluran pencernaan ayam kampung (Gallus domesticus). Prosiding Seminar Nasional Sains, Matematika, Informatika dan Aplikasinya 3 (3): 306311. [Indonesian]

Vilas-Boas GT, Peruca APS, Arantes OMN. 2007. Biology and taxonomy of Bacillus cereus, Bacillus anthracis, and Bacillus thuringiensis. Can J Microbiol 57: 673-687. DOI: 10.1139/W07-029.

Yanti Y, Warnita, Reflin, Nasution CR. 2018. Characterizations of endophytic Bacillus strain from tomato roots as growth promoter and biocontrol of Ralstonia solanacearum. Biodiversitas 19 (3): 906-911. DOI: $10.13057 /$ biodiv/d190320

Zhang HS. 2016. Two new secondary metabolites from the endophytic fungus Endomelanconiopsis endophytica. Molecules 21 (943): 1-6. DOI: 10.3390/molecules21070943. 